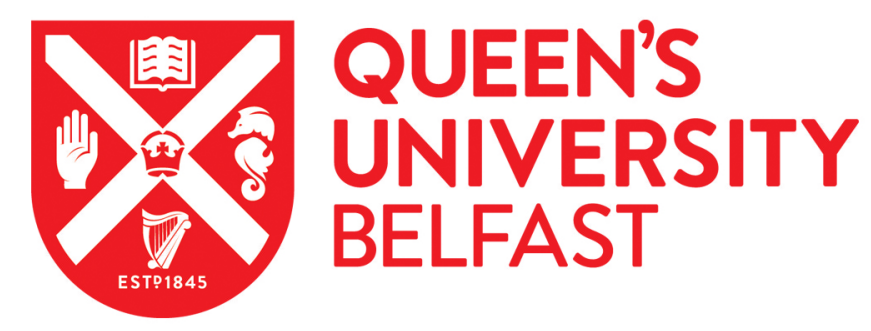

\title{
Impact of political violence, social trust, and depression on civic participation in Colombia
}

Taylor, L. K. (2016). Impact of political violence, social trust, and depression on civic participation in Colombia. Peace and Conflict: Journal of Peace Psychology , 22(2), 145-152. https://doi.org/10.1037/pac0000139

Published in:

Peace and Conflict: Journal of Peace Psychology

Document Version:

Peer reviewed version

Queen's University Belfast - Research Portal:

Link to publication record in Queen's University Belfast Research Portal

Publisher rights

(c) 2015 American Psychological Association

This article may not exactly replicate the final version published in the APA journal 'Peace and Conflict'. It is not the copy of record.

\section{General rights}

Copyright for the publications made accessible via the Queen's University Belfast Research Portal is retained by the author(s) and / or other copyright owners and it is a condition of accessing these publications that users recognise and abide by the legal requirements associated with these rights.

Take down policy

The Research Portal is Queen's institutional repository that provides access to Queen's research output. Every effort has been made to ensure that content in the Research Portal does not infringe any person's rights, or applicable UK laws. If you discover content in the Research Portal that you believe breaches copyright or violates any law, please contact openaccess@qub.ac.uk. 
Running Header: POLITICAL VIOLENCE \& CIVIC PARTICIPATION

Impact of political violence, social trust, and depression on civic participation in Colombia

Laura K. Taylor

Queen's University, Belfast

Correspondence should be directed to Laura K. Taylor, Lecturer (Assistant Professor) in the School of Psychology, Queen’s University, Belfast (1.taylor@qub.ac.uk). This research was funded by a Kellogg Institute Graduate Research Grant, Kroc Institute Graduate Research Summer Funding and Institute for Scholarship in the Liberals Arts Graduate Student Research Award from the University of Notre Dame. I would like to thank the many individuals who have participated in the project, including the support of the Citizens Commission for Reconciliation in the Caribbean (CCRC), the research teams at the University of Sinú, Córdoba, and CECAR, Sucre, and David Backer for his consultation. I am grateful to John Paul Lederach and the members of the Peacebuilding Apprenticeship program for their guidance and support. 


\begin{abstract}
Civic participation is important for peacebuilding and democratic development; however, the role of mental health has been largely overlooked by policymakers aiming to stimulate engagement in civil society. This study investigated antecedents of civic participation in Colombia, a setting of protracted political conflict, using bootstrapped mediation in path analysis. There was a significant, positive direct effects between past exposure to violence, experience with community antisocial behavior, and perceived social trust on civic participation. In addition, depression mediated the impact of past exposure to political violence and perceived social trust, but not community antisocial behavior, on civic participation. In this context, findings challenged depictions of helpless victims and instead suggested that individuals respond in constructive ways, taking on agency in their communities, when facing greater risk (past violence exposure and community antisocial behavior). Social trust in one's neighbors and community also facilitated deeper engagement in civic life. Relevant to the mediation test, interventions aiming to increase civic participation should take mental health into account. Limitations and possible future research are discussed.
\end{abstract}

Key words: civic participation; mental health; social trust; political violence; Colombia 
Impact of political violence, social trust, and depression on civic participation in Colombia

A strong civil society has the potential to support peacebuilding initiatives which aim to transform a history of violent conflict (Paffenholz \& Spurk, 2006). However, in settings of protracted conflict, there are a number of factors that may undermine participation in civic life. For example, past studies have shown that exposure to political violence is a risk factor that adversely affects individual well-being (Puac-Polanco et al., 2015; Sousa, 2013); mental health, in turn, is integrally related to civic participation (Almedom, 2005). Despite this connection, mental health is frequently overlooked by policymakers interested in ending conflict and building democracy (Kaufman, 2006; Shapiro, 2010). Settings of political violence are also often plagued by antisocial behavior that is not specifically related to the conflict dynamics (Taylor et al., 2011). These forms of on-going community antisocial behavior may also affect an individual's willingness to engage in community life and can be a risk factor for mental health problems (Chen, Propp, \& Lee, 2015; Taylor et al., 2013). However, despite adversity, individuals may also rely on important resources; for example, social trust and support may increase levels of community engagement and bolster mental health (Verduin, Smid, Wind, \& Scholte, 2014). Following a psychosocial model, the current study assessed how external factors (e.g. risks or resources) influenced internal mental states (e.g. depression), which in turn affected behavior (e.g. civic participation). These relations were examined in the Caribbean coast of Colombia, a region with robust civil society movements despite on-going violence.

\section{Risks and Resources related to Civic Participation}

Civic participation may have long-term peacebuilding implications (Paffenholz \& Spurk 2006). Across a range of contexts, civic participation has been shown to prevent the outbreak of 
ethnic riots (Varshney, 2001), enhance peace negotiations (Cross, 2004), and strengthen reconciliation (Hamber, 2009). Outside the state system, civil society provides a non-violent mechanism to channel voices of dissent to policymakers (Chirot \& McCauley, 2006). Civic participation may also strengthen social networks through cross-cutting social ties, which have been shown to prevent violent outbreaks (Varshney, 2001). This research reflects an inclusive conceptualization civil society; it shows that not only peacebuilding non-governmental organizations, but also diverse types of community groups may contribute to positive social change. For example, sports or recreation events have been used to promote reconciliation (Höglund \& Sundberg, 2008). The church has also played an important peacebuilding role in many societies, including Colombia (Gaviria, 2009). Finally, political and community development groups offer the potential to deepen democratic engagement at the local level (Corona, 2004). Thus, with this broad working definition of civic participation, the study will examine factors that relate to more active engagement in a range of groups that may promote conflict transformation (Kriesberg, 2006).

One factor that may be related to the peacebuilding potential of civic participation is past political violence, or the use of threats and direct aggression between armed combatants for political objectives. Although some studies have found that political violence may dampen social engagement among survivors (Pedersen, 2002; Sousa, 2013), another body of research suggests that political violence can mobilize feelings of solidarity and social engagement (see Barber, 2009; Vollhardt, 2009). The latter set of relations may be explained by altruism born of suffering; this theory explains how individuals who have suffered past harms, may be motivated to help other members of society (Vollhardt, 2009). For example, youth exposed to political violence were more likely to engage in activism for societal change (Barber, 2009). Although 
there may be negative consequences for other domains of functioning, such as mental health, this research suggests that exposure to political violence may promote engagement in civic life.

However, not all forms of violence affect people in the same way. That is, past violence rooted in political conflict between armed groups (e.g. forced displacement) may function in distinct ways from current community violence, or antisocial behaviors that can occur in any setting (e.g., home robberies). These forms of community antisocial behavior may tear at the social fabric of communities. Research has found that experience with community violence was related to lower levels of volunteering and civic engagement (Chen et al., 2015). Experiencing negative events in the community may also challenge a sense of a shared social order (JanoffBulman \& Frieze, 1983). Therefore, community-related stressors such as antisocial behavior may curtail or dampen the motivation to work with and for others. Balancing these risk factors, other social resources may also influence individual civic participation.

One factor underlying strong community relations and a vibrant civil society is social trust, or the positive expectation about others' intentions, motivations and behaviors (Tam, Hewstone, Kenworthy, \& Cairns, 2009). Perceived social trust has been shown to relate to a host of constructs at the individual, community, and national levels, such as well-being, participation in civil society, and democratic development (Delhey \& Newton, 2003; Stolle, 1998). For example, in a national study in Colombia, interpersonal trust provided a sense of security and safety that was linked with behaviors related to community belonging (Hurtado, Kawachi, \& Sudarsky, 2011). These findings suggest that social trust may be a necessary antecedent for an individual to decide to take part in community organizations. To further this review of the direct effects of various risks and resources on civic participation, the following section will discuss the potential mediating role of mental health in these relations. 


\section{Mental Health in Conflict Settings}

Mental health, or internal well-being related to psychological distress (Puac-Polanco et al., 2015), may be negatively affected by both political violence and community antisocial behavior. For example, past exposure to political violence has been shown to have long-lasting effects on adult mental health (Merrilees et al., 2011). Civilians affected by political violence, such as those who have survived forced displacement, may be susceptible to negative mental health outcomes, such as internalizing problems, depression and post-traumatic stress symptoms (Siriwardhana \& Stewart, 2013; Sousa, 2013). In addition, research has found that levels of community violence to are positively related to internalizing problems (Beiser, Wiwa, \& Adebajo, 2010). By eroding feelings of safety and security, both past exposure to political threat and living in an environment of on-going antisocial behavior are related to higher levels of psychological distress.

Yet even in settings of risk, there may be personal and social resources that are linked with fewer mental health symptoms. Social trust between individuals in a group and across groups is related to improved mental health (Almedom, 2005); the degree that individuals can access these social resources can positively affect well-being. For example, in South Africa, social trust was associated with lower levels of depression (Tomita \& Burns, 2013). These factors are important because poor mental health has other social implications. Depression, for example, is related to social withdrawal (Cruwys et al., 2014), which may be related to lower levels of civic participation. To better understand the role of mental health as it relates to these risks, resources, and civic participation, the current study will build on this past research to examine these relations in a setting of protracted conflict. 


\section{Caribbean Coast of Colombia}

Although over 50 years of internal armed conflict has adversely affected many in Colombia, the Caribbean coast has an important history of paramilitarism, demobilization through the 2005 Justice and Peace Law, and subsequent resurgence of crime and narcotrafficking (ICG, 2006; Restrepo et al., 2006). In the 1990s, paramilitaries, originally organized as private self-defense groups enjoying support of the state, began participating in the drug trade and consolidated into the United Self-Defense Forces of Colombia (AUC). As their power increased, so did land seizures and forced displacement for the cultivation of illicit crops and to access ports on the Caribbean (Saab \& Taylor, 2009). Despite demobilization of approximately 32,000 members of the AUC and other paramilitary factions through the Justice and Peace Law (Tate, 2009), the violence in Colombia continues, particularly along the Caribbean coast where approximately one-third of the collective demobilized paramilitary groups occurred (ICG, 2006). Since the initiation of demobilization in 2005 , there has been a steady expansion of illegal groups around narcotrafficking, largely comprised of former paramilitary members; this phenomenon is linked to community antisocial behavior and has created a sense of insecurity and instability in the Caribbean coast (ICG, 2008).

Despite decades of war, Colombia has maintained a vibrant civil society (Bouvier, 2009; Negrete \& Garcés, 2010), which has helped Colombians resist and repeal some of the negative consequences of such violence (Sánchez, 2013). For example, the Caribbean region has been home to a number of local community efforts to transform the conflict through creative and nonviolent means (Esquivias-Ballesta \& Gerbich, 2009). Thus, with a history of violence and strong civil society movements (CNRR, 2010), this region represents an important area to understand the dynamics among peacebuilding efforts amid protracted conflict. 


\section{Current Study}

Based on this literature, two research questions guided this study in the Caribbean coast of Colombia: First, which factors affect civic participation? Second, does mental health mediate these relations? Based on altruism born of suffering, it was hypothesized that past exposure to political violence would be related to greater participation in civil society (H1). In addition, two variables reflecting current individual experiences in social settings were considered: one risk factor, community antisocial behavior, and one positive factor, perceived social trust. It was expected that on-going experience with community antisocial behavior would be related to lower levels of civic participation (H2), but that perceived social trust would be linked higher levels of engagement in civic life (H3). Finally, it was expected that mental health would mediate these relations such that more depressive symptoms would be related to lower levels of civic participation (H4).

\section{Method}

\section{Design}

The research was conducted in Córdoba and Sucre, two departments along the Caribbean coast of Colombia. It was a correlation study that compared between-person levels on the constructs of interest. As a guideline for recruitment described below, initial power analyses indicated that a sample of 147 participants would be sufficient to detect medium effect sizes (.15) at $p<.05$, with a power of .80, in multiple regression with up to 8 predictors (Cohen, 1992).

\section{Participants}

The development of the sampling frame and participant recruitment procedures was carried out with two university partners, each with a history of engaged scholarship and community involvement. Across Córdoba and Sucre, in collaboration with four experts at the 
partnering universities, municipalities were selected to generate within-case variation on past and current violence along with civic participation (Gerring, 2007). These choices were supported by the existing literature. For example, in Córdoba the higher violence municipalities had the greatest number of homicides from 2001 to 2008 (Negrete, 2008), whereas the lower violence municipalities ranked in the bottom half of displacements from 1996 to 2006 (CERAC, 2012). More leadership trainings were held in higher participation areas, whereas there were fewer local organizations in the lower participation municipalities in Córdoba (Negrete, 2008).

Within each municipality, approximately 10-15 participants were recruited to reflect representative sectors of the population in the Caribbean coast (Negrete, 2008; Negrete \& Garcés, 2010). Inclusion criteria directed researchers to Afro-Colombians, campesinos, churches, demobilized, displaced, indigenous, teachers, trade unionists, women, and conflict victims. Participants under the age of 18 were excluded from the study. Given the sensitive nature of the survey topics, local contacts facilitated recruitment of participants based on this purposeful sampling frame to ensure the security of the participants and research team, while increasing the validity of a non-probability sample (White \& McBurney, 2010).

These procedures resulted in a sample of 184 participants ( $49 \%$ men, $51 \%$ women) that were $42.50(S D=14.20$; range $19-89)$ years old on average and self-identified as mestizo $(55 \%)$, Afro-Colombian (14\%), indigenous (10\%), or chose more than one race/ethnicity. In addition, $67 \%$ were Catholic, 20\% Christian/Evangelical, and 13\% did not select a religion.

\section{Measures}

All measures and demographic questions were administered in Spanish. When an existing version of the measure was not available in Spanish, the questions were translated by the first author and then checked for accuracy by an external translator fluent in English and Spanish. The 
final wording of each question was refined through a brief pre-test and in consultation with faculty at a collaborating university; this ensured that each scale was appropriate to the context.

Past exposure to political violence. The measure was developed for post-conflict settings and has been used in Colombia (Backer, Kulkarni, \& Weinstein, 2007; Taylor, 2015a). Participants responded to ten questions about past exposure to violence that they had been exposed to directly during the conflict in Colombia. The responses were coded $0=n o$ and $1=y e s$ if the participants had experienced: detention without cause, physical torture, psychological torture, (being )beaten, sexual abuse or attack, witness to murder, threatened with violence, suffered damaged house or property, or forcibly displaced. Responses were added to get an overall frequency of past exposure to violence; possible scores ranged from 0 to 10 .

Community antisocial behavior. This 10 -item scale asked participants to indicate various types of current antisocial behaviors that $\mathrm{s} / \mathrm{he}$ experiences in the community. This Spanish-language measure was developed for the High Commission on Reintegration survey (ACR, 2007). Dichotomous responses, $0=$ no and $1=y e s$, were added to reflect a frequency score for the number of types of antisocial behaviors including murders, kidnappings, robberies, etc. The responses could range from 0 to 10 . A confirmatory two-factor analyses using maximum likelihood and promax rotation was conducted to determine the relation between this scale the measure of past political violence. Each item loaded onto its respective scale; limited crossloadings were low (.10 to .18) and in each case were less than half of the loading onto the primary scale. Moreover, the factors of past exposure to political violence and current community antisocial behavior were not correlated.

Perceived social trust. A six-item measure, previously used in Colombia, assessed the level of social trust participants (World Social Values Survey, 2005; see on-line Appendix). 
Participants responded on a four-point Likert scale from $0=$ no trust at all to $3=$ completely trust the extent to which they felt trust across a number of different domains such as family, community, new situations, etc. Possible scores ranged from 0 to 18 with acceptable internal consistency (Cronbach's $\alpha=.74)$. Higher scores could represent deeper trust and/or broader trust across more domains.

Depression. Depression was measured with the Center for Epidemiology's Depression (CESD: Radloff, 1977; Translation: Perczek, Carver, Price, \& Pozo-Kaderman, 2000), which has been used in other settings of political violence (Pat-Horenczyk et al., 2013; Taylor et al., 2013). The 20-item measure included a four-point Likert scale for how often during the last week participants have felt any of the following, ranging from $0=$ rarely or never to $3=$ a majority of the time. Possible items included feeling fearful, depressed, had difficulty concentrating, or thought that my life has been a disaster. Depression was computed as a composite variable with a range of 0 to 60 . The internal consistency of this measure was good (Cronbach's alpha $=.87$ ).

Civic participation. The level of engagement in civil society groups was assessed with 13 items compiled from the World Social Values Survey (2005) and the ACR (2007) survey (see on-line Appendix). Participants selected among three possible responses: if they were an $2=$ active member, $1=$ inactive member or $0=$ not a member of groups such as church, sports team, or community development organization. A composite indicator was calculated by summing the responses for each person, with a possible range of 0 to 26 and acceptable internal consistency (Cronbach's $\alpha=.75)$.

\section{Procedures}

The survey was administered in Spanish, the primary language of the participants, through face-to-face interviews lasting approximately 45 minutes by the PI or one of 16 trained 
research assistants from the collaborating universities, including faculty, recent graduates, and advanced undergraduates in psychology and conflict studies. All participants provided informed consent and received no compensation, consistent with the local practices. The study design, procedures, and measures were approved by the PI's Human Subjects Review Board.

\section{Results}

Analyses were conducted using a saturated path model in MPlus (Muthén \& Muthén, 1998-2007); estimates were derived using maximum likelihood estimation. Mediation was tested using a non-parametric, bias-corrected bootstrap approach with 1,000 resamples to construct a 95\% confidence interval around the indirect effects (Fritz \& MacKinnon, 2007; MacKinnon, Lockwood, \& Williams, 2004). This approach, particularly good for smaller sample sizes, offered a number of advantages compared to traditional mediation tests involving separate regressions (Baron \& Kenny, 1986; Sobel, 1982). In bootstrap mediation, relations among independent variables are controlled for and all of the direct and indirect effects are tested in a single model. The bootstrap approach calculated a confidence interval for the indirect effect (i.e., the effect of independent variable on the dependent outcome via the meditator); if the interval did not contain 0 , there was significant mediation. If the remaining direct effect (i.e., the path between the independent variable and the dependent outcome) was not significant, it was full mediation; if the direct effect remained significant, then it was partial mediation.

The ranges, means, standard deviations, and bivariate correlations for all constructs are included in Table 1. The percentage of active and inactive membership in each type of organization is presented in Table 2. Regarding the first research question, there were mixed effects for the antecedents of civic participation (Figure 1). First, past exposure to violence was positively related to civic participation $(\beta=.24, p<.01)$, and predicted more depressive 
symptoms $(\beta=.20, p<.01)$. Second, contrary to predictions, greater antisocial behavior in the community was related to higher levels of civic participation $(\beta=.24, p<.001)$ and was nonsignificantly related to depression. Third, perceived social trust related to more civic participation $(\beta=.17, p<.05)$ and to fewer mental health problems $(\beta=-.23, p<.01)$. Finally, participants with higher levels of depression were less likely to participate in civic organizations, significant at the trend level $(\beta=-.15, p=.058)$. These standardized regression coefficients can be interpreted as the percent change in the standard deviation of the outcome expected for every standard deviation increase in the predictor. For example, an increase of approximately three points in perceived social trust (e.g., from none to total trust in one domain), would be related to an increase of one point for civic participation (e.g., becoming an inactive member of a new group, or shifting from an inactive to an active member of an organization).

Supporting the second research question about the mediating role of mental health, two of the three pathways were partially mediated by depression. That is, the effects of past exposure to violence $(\beta=-.11, \mathrm{CI}:-.317,-.003, p<.05)$ and perceived social trust $(\beta=.06, \mathrm{CI}: .004, .138$, $p<.05)$ on civic participation were, in part, due to their impact on mental health. Depression, however, did not mediate the link between community antisocial behavior and engagement in civic life. The partially mediated pathways suggested that the role of mental health, specifically depression as related to past violence exposure and perceived social trust, should be considered by those interested in promoting civic participation.

\section{Discussion}

This study aimed to understand how different experiences affected mental health, which in turn influenced behavior. More specifically, analyses identified risks and resources related to diverse forms of civic participation and the mediating role of depression in these pathways. 
Consistent with previous research, past exposure to political violence positively predicted civic participation, supporting the theory of altruism born of suffering. Greater social trust also was also positively related to greater engagement in civic life. However, contrary to expectations, community antisocial behavior was positively related to civic participation and did not significantly relate to depression. Finally, there was support for the importance of mental health in these processes; depressive symptoms partially mediated the influence of past exposure to political violence and perceived social trust on civic participation.

In the Caribbean coast of Colombia, the organizations with the most active participation were church or religious communities, political groups, recreational or sport organizations, and community development groups. This range of organizations was consistently with previous research that has more broadly examine the impact of cross-cutting social ties, rather than reducing civic participation to peacebuilding organizations. That is, these forms of social bonding and relations, not necessarily intentionally directed toward conflict transformation, may still be able to prevent violent outbreak and deepen reconciliation initiatives (Hamber, 2009; Varshney, 2001). Those interested in 'building peace in a time of war' (Bouvier, 2009) may look to partner with and strengthen these existing social networks in the Caribbean coast of Colombia (Esquivias-Ballesta \& Gerbich, 2009). The following discussion elaborates on what other factors should be considered in these efforts.

Past exposure to political violence, current experience with community antisocial behavior, and perceived social trust were all positively related to civic participation. These findings suggest that in this setting of protracted conflict, community antisocial behavior does not dampen engagement in civic life. Instead, as with past political violence, responses to community antisocial behavior may be affected by altruism born of suffering (Vollhardt, 2009). 
Feeling a lack of safety in the community may motivate those who experience community antisocial behavior to establish bonds with other victims. In the face of both political and community violence, individuals may be motivated to act prosocially and help others through community engagement (Taylor et al., 2014). These results challenge depictions of those exposed to violence as helpless victims; instead, the findings converge with other studies that recognize the agency and constructive ways individuals respond to political violence and community conflict (see Barber, 2009). Of course, this does not suggest that individuals need to be exposed to violence in order to engage in civic life, but rather calls attention to resilience in the face of multiple forms of risk.

Continuing the focus on resilience factors, the findings also suggest the social trust was an important resource to promote civic participation. Deeper trust in friends and neighbors was related to taking on a greater role in civil society. Controlling for experiences related to the conflict and public safety, social trust was related to participation in voluntary organizations (Delhey \& Newton, 2003). This finding is consistent with the conceptualization of the model which proposed that social trust was necessary for an individual to decide to take part in community life.

The findings also pointed to the importance of mental health for civic participation, specifically as related to past exposure to political violence and perceived social trust. In the case of past political violence, for example, depression may act as a suppressor effect. That is, although individuals who were exposed to a greater number of adverse events during the conflict took on more active roles in civil society, this effect was undone to the degree that they suffered mental health problems as a result of those past traumas. Perceived social trust, on the other 
hand, functioned in a more straightforward way. That is, greater social trust related to fewer depressive symptoms, which it turn was related to more active civic participation.

Limitations of the current study include the cross-sectional data, sampling approach, and construct measurement. The goal of mediation is to identify causal mechanisms, or how and why processes unfold. Despite limitations to testing these processes with cross-sectional data, these findings may indicate promising future directions. Future research would benefit from multiple time points which could also model reciprocal effect among these constructs. The non-random sample was another constraint in the generalizability of these findings; because of security concerns for the research team, a purposeful sampling frame was developed to generate withincase variation and gather a diversity of relevant experiences. As security conditions change, or if other means of data collection are used (e.g. online, telephone), it may be possible to replicate this study with a random sample. Replication of the study would also be strengthened by additional forms of measurement. For example, more refined measures of civic participation and post-traumatic stress responses could complement the current findings. Future research could also extend this study by including additional factors, such as coping mechanisms (Taylor, 2015b), that may moderate the links between violence, mental health, and civic participation.

Despite these areas for improvement and expansion, the results have implications for practice and policy in protracted conflict settings. Intervention programs that are able to deepen trust within a domain, such as the neighborhood, or across domains, may encourage more active participation in community organizations (Almedom, 2005). Moreover, the findings highlighted the need to minimize depressive symptoms for individuals exposed to political violence (Bolton et al., 2014). The mediation findings identify mental well-being as a factor that should be taken into account by programs aiming to increase civic participation as a tool for peacebuilding. It 
may not be sufficient to create more opportunities for civic engagement; instead, psychosocial support may be necessary for those who have been exposed to past violence or who live in areas with deteriorated social trust. Many individuals living in settings of on-going conflict fit this profile. More broadly, these findings encourage a broader conceptualization of civic participation and greater attention to emotions and mental health by policymakers focused on inclusive peacebuilding and democratic development (Kaufman, 2006; Shapiro, 2010). 


\section{References}

Almedom, A. M. (2005). Social capital and mental health: An interdisciplinary review of primary evidence. Social Science \& Medicine, 61, 943-964.

Alta Consejería para la Reintegración (ACR, 2007). Social y Económica de Personas y Grupos Aliados en Armas, Presidencia de la República de Colombia.

Backer, D., Kulkarni, A., \& Weinstein, H. (2007). West Africa Transitional Justice Project Liberia Questionnaire (First Wave).

Barber, B. K. (Ed.) (2009). Adolescents and war: How youth deal with political violence. New York, NY, US: Oxford University Press.

Baron, R. M., \& Kenny, D. A. (1986). The moderator-mediator variable distinction in social psychological research: Conceptual, strategic and statistical considerations. Journal of Personality and Social Psychology, 51, 1173-1182.

Beiser, M., Wiwa, O., \& Adebajo, S. (2010). Human-initiated disaster, social disorganization and post-traumatic stress disorder above Nigeria’s oil basins. Social Science \& Medicine, $71(2), 221-227$.

Bolton, P., Bass, J. K., Sabir Zangana, G. A., Kamal, T., Murray, S. M., Kaysen, D., \& ... Rosenblum, M. (2014). A randomized controlled trial of mental health interventions for survivors of systematic violence in Kurdistan, Northern Iraq. BMC Psychiatry, 14(1), 23 59.

Bouvier, V. (Ed.) (2009). Colombia: Building peace in a time of war. Washington DC: United States Institute of Peace. 
Centro de Recursos para el Análisis de Conflictos (CERAC) (2012). Base de datos sobre conflicto Armado Colombiano: Desplazamiento forzado interno (1996-2006). Retrieved from http://www.cerac.org.co/pdf/IFD_nivel\%20V9\%20240907SoloLectura.pdf

Chen, W., Propp, J., \& Lee, Y. (2015). Connection between adolescent's exposure to community violence and future civic engagement behaviors during their young adulthood. Child \& Adolescent Social Work Journal, 32(1), 45-55.

Chirot, D. \& McCauley, C. (2006). Why not kill them all? The logic and prevention of mass political murder. Princeton, NJ: Princeton University Press.

Comisión Nacional de Reparaciones y Reconciliación (CNRR) (2010). La Tierra en Disputa: Memorias de Despojo y Resistencia Campesina en la Costa Caribe (1960-2010). Colombia: Colombo Andina de Impresos S.A.

Cohen, J. (1992). A power primer. Psychololigcal Bulletin, 112(1):155-159.

Corona, A. R. (2004). Los retos de la democracia participativa. Sociológica, 15(54), 183-211.

Cross, S. (2004). A just path to peace: A narrative of the life and work of Luz Méndez. Retrieved from https://lib.sandiego.edu/peacestudies/documents/institutes/ipj/luz-mendez.pdf

Cruwys, S. T., Haslam, A., Dingle, G. A., Jetten, J., Hornsey, M. J., Chong, E. M. D., \& Oei, T. R. S. (2014). Feeling connected again: Interventions that increase social identification reduce depression symptoms in community and clinical settings. Journal of Affective Disorders, 159(20), 139-146.

Delhey, J. \& Newton, K. (2003). Who trusts?: The origins of social trust in seven societies. European Societies, 5(2), 93-137. 
Esquivias-Ballesta, R., \& Gerbich, B. (2009). The local community as a creative space for transformation. In V. Bouvier (Ed.), Colombia: Building peace in a time of war (pp. 295310). Washington DC: United States Institute of Peace.

Fritz, M. S., \& MacKinnon, D. P. (2007). Required sample size to detect the mediated effect. Psychological Science, 18(3), 233-239.

Gaviria, H. F. (2009). The Colombian church and peacebuilding. In V. Bouvier (Ed.), Colombia: Building peace in a time of war (pp. 173-190). Washington DC: United States Institute of Peace.

Gerring, J. (2007). Case study research: Principles and practices. Cambridge: Cambridge University Press.

Hamber, B. (2009). Transforming societies after political violence: Truth, reconciliation, and mental health. United Kingdom: Springer.

Höglund, K., \& Sundberg, R. (2008). Reconciliation through Sports? The case of South Africa. Third World Quarterly, 29(4), 805-818.

Hurtado, D., Kawachi, I., \& Sudarsky, J. (2011). Social capital and self-rated health in Colombia: The good, the bad and the ugly. Social Science \& Medicine, 72(4), 584-590. International Crisis Group (ICG) (2008). Correcting course: Victims and the Justice and Peace Law in Colombia. (Latin America Report №29). Retrieved from http://www.crisisgroup.org/ /media/Files/latin-america/colombia/recting_course _victims_and_the_justice_and_peace_law_in_colombia.pdf International Crisis Group (ICG) (2006). Colombia: Towards peace and justice? (Latin America Report N816). Retrieved from http://www.crisisgroup.org/,/media/Files/latinamerica/ colombia/16_colombia_towards_peace_and_justice 
Janoff-Bulman, R., \& Frieze, I. H. (1983). A theoretical perspective for understanding reactions to victimization. Journal of Social Issues, 39, 1-17.

Kaufman, S. J. (2006). Escaping the symbolic politics trap: Reconciliation initiatives and conflict resolution in ethnic wars. Journal of Peace Research, 43(2), 201-218.

Kriesberg, L. (2006). Constructive conflicts: From escalation to resolution ( $3^{\text {rd }}$ edition). Lanham, MD: Rowman \& Littlefield.

MacKinnon, D. P., Lockwood, C. M., \& Williams, J. (2004). Confidence limits for the indirect effect: Distribution of the product and resampling methods. Multivariate Behavioral Research, 39(1), 99-128.

McCouch, R. J. (2009). The effects of wartime violence on young Bosnians' postwar behaviors: Policy contours for the reconstruction period. In B.K. Barber (Ed.), Adolescents and war: How youth deal with political violence (pp. 177-204). New York, NY, US: Oxford University Press.

Merrilees, C. E., Cairns, E., Goeke-Morey, M. C., Schermerhorn, A. C., Shirlow, P., \& Cummings, E. M. (2011). Associations between mother's experience with the Troubles in Northern Ireland and mother's and children's psychological functioning: The moderating role of social identity. Journal of Community Psychology, 39(1), 60-75.

Muthén, L. K. and Muthén, B. O. (1998-2007). Mplus User's Guide (5 ${ }^{\text {th }}$ Edition). Los Angeles, CA: Muthén \& Muthén.

Negrete, V. (2008). Situación de conflicto y pobreza en el departamento de Córdoba y perspectivas de paz. Montería, Colombia: Louis Ángel Asocioado y Cia Ltda. 
Negrete, V. \& Garcés, M. (2010). Análisis sociopolítico de Montería y propuestas sobre liderazgo, participación y compromiso ciudadano. Montería, Colombia: Universidad del Sinú.

Paffenholz, T., \& Spurk, C. (2006). Civil society, civic engagement, and peacebuilding. Social Development Papers: Conflict Prevention \& Reconstruction, Paper No. 36. Retrieved from http://siteresources.worldbank.org/INTCPR/Resources/WP36_web.pdf

Pat-Horenczyk, R., Ziv, Y., Asulin-Peretz, L., Achituv, M., Cohen, S., \& Brom, D. (2013). Relational trauma in times of political violence: Continuous versus past traumatic stress. Peace and Conflict: Journal of Peace Psychology, 19(2), 125-137.

Pedersen, D. (2002). Political violence, ethnic conflict, and contemporary wars: broad implications for health and social well-being. Social Science \& Medicine, 55, 175-190.

Perczek, R., Carver, C. S., Price, A. A., \& Pozo-Kaderman, C. (2000). Coping, mood, and aspects of personality in Spanish translation and evidence of convergence with English versions. Journal of Personality Assessment, 74, 63-87. The Spanish version is available http://www.psy.miami.edu/faculty/ccarver/sclspan.html, accessed on July 21, 2010.

Puac-Polanco, V. D., Lopez-Soto, V. A., Kohn, R., Dawei, X., Richmond, T. S., \& Branas, C. C. (2015). Previous violent events and mental health outcomes in Guatemala. American Journal of Public Health, 105(4), 764-771.

Radloff, L. S. (1977). The CES-D: A self-report depression for research in the general population. Applied Psychological Measurement, 1, 385-401.

Restrepo, J., Spagat, M., \& Vargas, J. (2006). The severity of the Colombian conflict: Crosscountry datasets versus new micro-data. Journal of Peace Research, 43(1), 99-115. 
Saab, B. Y. \& Taylor, A. W. (2009). Criminality and armed groups: A comparative study of FARC and paramilitary groups in Colombia. Studies in Conflict \& Terrorism, 32, 455475.

Sánchez, G. (2013). Prólogo. In ¡Basta ya! Colombia: Memorias de guerra y dignidad (pp. 1316). Retrieved from http://www.elpais.com.co/elpais/archivos/bastaya.pdf Shapiro, D. L. (2010). Relational identity theory: A systematic approach for transforming the emotional dimension of conflict. American Psychologist, 65(7), 634-645.

Siriwardhana, C., \& Stewart, R. (2013). Forced migration and mental health: prolonged internal displacement, return migration and resilience. International Health, 5(1), 19-23.

Sobel, M. E. (1982). Asymptotic confidence intervals for indirect effects in structural equation models. Sociological Methodology, 13, 290-312.

Sousa, C. A. (2013). Political violence, collective functioning and health: A review of the literature. Medicine, Conflict and Survival, 29:3, 169-197.

Stolle, D. (1998). Bowling together, bowling alone: The development of generalized trust in voluntary associations. Political Psychology, 19(3), 497-525.

Tate, W. (2009). From greed to grievance: The shifting political profile of the Colombian paramilitaries. In V. Bouvier (Ed.), Colombia: Building peace in a time of war (pp. 111132). Washington DC: United States Institute of Peace.

Tam, T., Hewstone, M., Kenworthy, J., \& Cairns, E. (2009). Intergroup trust in Northern Ireland. Personality and Social Psychology Bulletin, 35, 45-59.

Taylor, L. K. (2015a). Transitional justice, demobilization, and peacebuilding amid political violence: Examining individual preferences in the Caribbean coast of Colombia. Peacebuilding, 3(1), 90-108. 
Taylor, L. K. (2015b). Implications of coping strategies and community cohesion for mental health in Colombia. In D. Christie, S. Suffla and M. Seedat (Eds), Enlarging the Scope of Peace Psychology - African and World-Regional Contributions. Switzerland: Springer Peace Psychology Book Series.

Taylor, L. K., Merrilees, C. E., Goeke-Morey, M. C., Shirlow, P., Cairns, E., \& Cummings, E. M. (2014). Political violence and adolescent outgroup attitudes and prosocial behaviors: Implications for positive intergroup relations. Social Development, 23(4), 840-859.

Taylor, L. K., Merrilees, C. E., Cairns, E., Goeke-Morey, M. C., Shirlow, P., \&. Cummings, E. M. (2013). Risk and resilience: The moderating role of social coping for maternal mental health in a setting of political conflict. International Journal of Psychology, 48(4), 591603.

Taylor, L. K., Merrilees, C. E., Campbell, A., Shirlow, P., Cairns, E., Goeke-Morey, M. C., Schermerhorn, A. C., \& Cummings, E. M. (2011). Sectarian and nonsectarian violence: Mothers' appraisals of political conflict in Northern Ireland. Peace and Conflict: Journal of Peace Psychology, 17(4), 343-366.

Tomita, A., \& Burns, J. K. (2013). A multilevel analysis of association between neighborhood social capital and depression: Evidence from the first South African National Income Dynamics Study. Journal of Affective Disorders, 144(1-2), 101-105.

Varshney, A. (2001). Ethnic conflict and civil society: India and beyond. World Politics, 53(3); $362-398$.

Verduin, F., Smid, G. E., Wind, T. R., \& Scholte, W. F. (2014). In search of links between social capital, mental health and sociotherapy: A longitudinal study in Rwanda. Social Science \& Medicine, 1211-1219. 
Vollhardt, J. R. (2009). Altruism born of suffering and prosocial behavior following adverse life events: A review and conceptualization. Social Justice Research, 22, 53-97.

White, T. L., \& McBurney, D. H. (2010). Research Methods (9 $9^{\text {th }}$ edition). Belmont, CA: Wadsworth, Cengage Learning.

World Social Values Survey (2005). Retrieved from http://www.worldvaluessurvey.org/wvs/ articles/folder_published/survey_2005 
Table 1

Ranges, Means, Standard Deviations and Bivariate Correlations for All Manifest Variables (N=184)

\begin{tabular}{|c|c|c|c|c|c|c|c|c|c|}
\hline \multicolumn{2}{|c|}{ Variables } & \multirow{2}{*}{$\begin{array}{c}\text { Min } \\
0\end{array}$} & \multirow{2}{*}{$\begin{array}{c}\text { Max } \\
9\end{array}$} & \multirow{2}{*}{$\begin{array}{c}\text { Mean } \\
0.48\end{array}$} & \multirow{2}{*}{$\begin{array}{c}S D \\
1.21\end{array}$} & \multirow{2}{*}{$\begin{array}{l}1 \\
-\end{array}$} & \multirow[t]{2}{*}{2} & \multirow[t]{2}{*}{3} & \multirow[t]{2}{*}{4} \\
\hline 1 & Past Violence Exposure & & & & & & & & \\
\hline \multirow[t]{2}{*}{2} & Experience with Community & 0 & 11 & 5.81 & 2.93 & 0.09 & - & & \\
\hline & Antisocial Behavior & & & & & & & & \\
\hline 3 & Perceived Social Trust & 1 & 17 & 9.99 & 3.23 & 0.02 & 0.03 & - & \\
\hline 4 & Depression & 0 & 44 & 16.57 & 10.45 & $0.20^{*}$ & 0.08 & $-0.20^{*}$ & - \\
\hline 5 & Civic Participation & 0 & 20 & 5.43 & 4.49 & $0.24 * *$ & $0.25^{* *}$ & $0.28 * *$ & -0.11 \\
\hline
\end{tabular}

Note $:{ }^{*} p<.05 ; * * p<.01$ 
Table 2

Percentage of participants that report membership across different civil society organizations in the Caribbean coast of Colombia

\begin{tabular}{lccc}
\hline Organization & Not a & Inactive & Active \\
& Member & Member & Member \\
\hline 1. Church or religious organization & $31 \%$ & $19 \%$ & $50 \%$ \\
2. Sport or recreational organization & $64 \%$ & $11 \%$ & $25 \%$ \\
3. Art or music organization & $84 \%$ & $6 \%$ & $10 \%$ \\
4. Union & $91 \%$ & $3 \%$ & $6 \%$ \\
5. Political party or group & $62 \%$ & $6 \%$ & $32 \%$ \\
8. Humanitarian or charitable organization & $72 \%$ & $7 \%$ & $21 \%$ \\
9. Academic group & $75 \%$ & $5 \%$ & $20 \%$ \\
10. Cooperative & $84 \%$ & $6 \%$ & $10 \%$ \\
11. Community development group & $69 \%$ & $6 \%$ & $25 \%$ \\
12. Youth group & $84 \%$ & $6 \%$ & $10 \%$ \\
13. Community Action Board (JAC) & $72 \%$ & $6 \%$ & $22 \%$ \\
\hline
\end{tabular}


Figure 1. Saturated path analysis of depression as a mediator of the impact of past violence exposure, perceived social trust, and experience with community antisocial behavior on civic participation $(\mathrm{N}=184)$. Error variances and correlations among endogenous predictors were omitted from the model for readability. Note: Standardized path coefficients reported; dotted lines represent non-significant paths. ${ }^{*} p<.05 ;{ }^{*} p<.01 ; * * * p<.001$ 


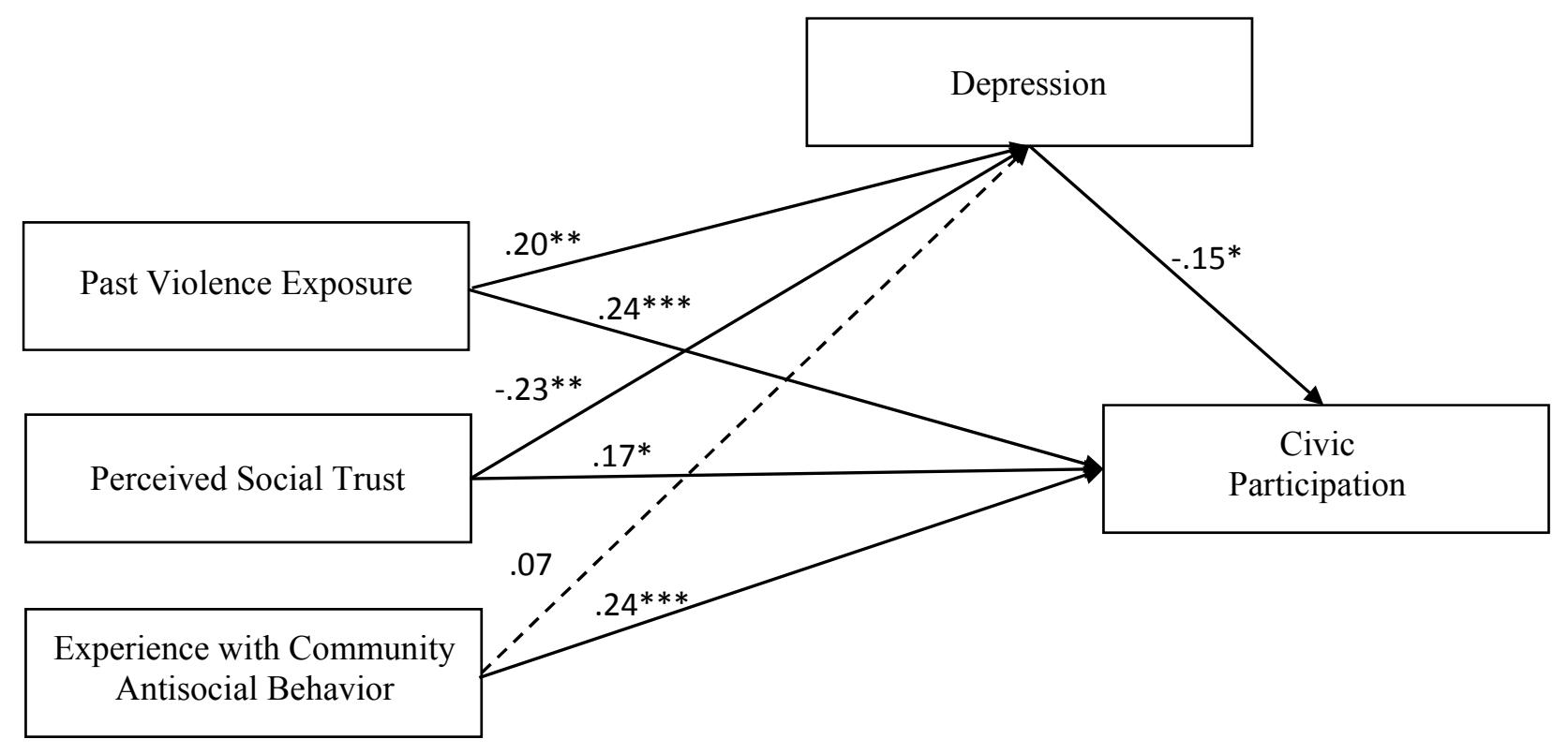

